\title{
Detection of chromosomal imbalances using combined MLPA kits in patients with syndromic intellectual disability
}

\author{
Detectarea dezechilibrelor cromozomiale folosind o combinație de kituri \\ MLPA la pacienții cu dizabilitate intelectuală sindromică
}

\begin{abstract}
Adriana Sireteanu ${ }^{1}$, Roxana Popescu ${ }^{2 *}$, Elena Emanuela Braha ${ }^{3}$, Cornel Bujoran ${ }^{1}$, Lăcrămioara Butnariu ${ }^{3}$, Lavinia $\mathrm{Caba}^{3}$, Elena Graur ${ }^{3}$, Eusebiu Vlad Gorduza ${ }^{3}$, Mihaela Grămescu3 ${ }^{3}$ Iuliu Cristian Ivanov³, Monica Pânzaru³, Cristina Rusu ${ }^{3}$

1. Medical Genetics Center, "Sf. Maria” Children's Hospital, Iaşi, Romania, 2. "Grigore T. Popa" University of Medicine and Pharmacy, Iassi, Romania, 3. Department of Medical Genetics, "Grigore T. Popa" University of Medicine and Pharmacy, Iaşi, Romania
\end{abstract}

\begin{abstract}
Intellectual disability (ID) is a common disorder, with major consequences for individual, family and society. Due to clinical and genetic heterogeneity of ID, in about 50\% of cases an etiologic diagnosis cannot be established. The aim of this study was to evaluate the ability of a combination of MLPA kits to establish the diagnosis in 369 patients with syndromic ID and normal or uncertain routine karyotype results. All patients were assessed for chromosome imbalance using SALSA MLPA P064 or P096 kits, if the phenotype was suggestive of a microdeletion syndrome (subgroup A - 186 patients), or subtelomeric P036 and P070 kits, if the phenotype was not suggestive of a microdeletion syndrome or if the result of the standard karyotype was uncertain (subgroup B - 183 patients). Abnormal results detected by these kits were further characterized using appropriate follow-up MLPA kits (Telomere Follow-up set, P029-A1, P250-B2, ME028-B1). In subgroup A we identified 25 patients with microdeletions $(13.4 \%)$. Using subtelomere screening and follow-up kits in subgroup B we detected cryptic rearrangements in $7.5 \%$ cases and identified the origin of the unknown material noticed in the standard karyotype in 10 out of 11 patients. Summarizing data from the two groups, the combined use of MLPA kits led to the diagnosis in 10.6\% (38/358) patients with normal karyotype. Using follow-up MLPA kits allowed us both to confirm abnormalities and to determine their size, which facilitated the interpretation of the clinical significance of these rearrangements. For laboratories that do not have yet access to microarray technology, using several MLPA kits represents an effective strategy for establishing the diagnosis in ID patients.
\end{abstract}

Key words: Intellectual disability;subtelomeric rearrangements;microdeletion syndromes;MLPA.

\section{Rezumat}

Dizabilitatea intelectuală (DI) este o afecțiune frecventă, cu consecințe majore pentru individ, familie și societate. Datorită heterogenității sale clinice și genetice, în aproximativ 50\% din cazuri etiologia bolii nu poate

*Corresponding author: Roxana Popescu, "Grigore T. Popa" University of Medicine and Pharmacy, Iaşi, Romania, e-mail: roxana.popescu2014@gmail.com 
fi stabilită. Scopul acestui studiu a fost evaluarea capacității de stabilire a diagnosticului etiologic la 369 pacienți cu DI sindromic și rezultat normal sau incert la cariotip folosind o combinație de kituri MLPA. Toţi pacienţii au fost investigaţi prin metoda MLPA, folosind fie kiturile SALSA MLPA P064 sau P096, dacă fenotipul a fost sugestiv pentru un sindrom cu microdeleţie (subgrupul A - 186 pacienți), fie kiturile subtelomerice P036 și P070, dacă fenotipul nu a fost sugestiv pentru un sindrom cu microdeleţie sau rezultatul la cariotipul standard a fost incert (subgrupul B - 183 pacienți). Rezultatele anormale detectate de aceste kituri au fost caracterizate folosind kiturile MLPA corespunzătoare de urmărire (Telomere Follow-up set, P029-A1, P250-B2, ME028-B1). In subgrupul A am identificat 25 de pacienți cu microdeleții (13,4\%). Folosind kiturile de screening subtelomeric și de urmărire la subgrupul B am detectat rearanjări criptice in 7,5\% din cazuri și am identificat originea materialului suplimentar observat la cariotipul standard la 10 din 11 pacienți. Sumarizând datele obținute din cele două loturi, folosirea combinată a seturilor MLPA a dus la stabilirea diagnosticului la 10,6\% (38/358) dintre pacienții cu cariotip normal. Folosirea seturilor MLPA de urmărire a permis atât confirmarea prezenţei anomaliei, cât şi determinarea dimensiunii ei, ceea ce a facilitat interpretarea semnificaţiei clinice a rearanjărilor. Pentru laboratoarele care $n u$ au acces la tehnologiile bazate pe microarray, folosirea mai multor kituri MLPA reprezintă o strategie eficientă pentru stabilirea diagnosticului etiologic la pacienţii cu DI.

Cuvinte cheie: Dizabilitate intelectuală, rearanjări subtelomerice, sindroame cu microdeleție, MLPA

Received: $4^{\text {th }}$ April 2014; Accepted: 18 ${ }^{\text {th }}$ May 2014; Published: $27^{\text {th }}$ May 2014.

\section{Introduction}

Intellectual disability (ID) is a major public health issue, with a prevalence that varies from less than $1 \%$ to $3 \%$ in the general population, depending on defining criteria used by different studies (1). ID etiology is complex, including exogenous and genetic factors, yet in approximately $50 \%$ of cases it remains unknown, either because patients were not genetically evaluated or because a genetic defect was not identified. Recent studies have shown that $15-20 \%$ of ID cases are caused by submicroscopic copy number variations (CNVs) $(2,3)$. The introduction of FISH (Fluorescence In Situ Hybridization) and MLPA (Multiplex Ligation-dependent Probe Amplification) techniques (4) enabled the detection of microdeletions / microduplications in syndromic ID patients (ID associated with dysmorphic features and/or multiple congenital anomalies). In the past decade, the introduction of the microarray technology has allowed the detection of submicroscopic CNVs with unprecedented resolution leading thus to the identification of numerous syndromes with microdeletions and microduplications (5), now chromosome microarray being recommended as a first-tier diagnostic test in pa- tients with ID and/or multiple congenital anomalies (2). However, this technology requires expensive equipment and consumables that are hardly accessible to all diagnostic centers. Some of the chromosomal abnormalities identified by microarray tests can also be detected using different MLPA kits. Taking into consideration the cost difference between whole genome microarray platforms and MLPA, screening ID patients using the MLPA technique represents a reasonable option in the diagnostic evaluation of ID, especially in the developing countries.

The aim of this study was to evaluate the ability of a combination of MLPA kits to establish the etiologic diagnosis in a group of patients with syndromic ID.

\section{Material and methods}

The study group consisted of 369 patients with syndromic ID of unknown etiology, older than three months and with normal (358 patients) or uncertain karyotype results at 400550-band level (11 patients). Patients that were clinically suggestive for aneuploidies $(21,13$ and 18 trisomies) and Fragile $\mathrm{X}$ syndrome were not included in the study. All patients have been 
clinically evaluated by a geneticist. The standard evaluation included family and medical history (pre-, peri- and postnatal data), anthropometric measurements, detailed physical examination and psychological examination. A written informed consent was obtained prior to evaluation from either patients' parents or legal representatives and the study was approved by the Ethics Committee of the University of Medicine and Pharmacy, Iasi.

All patients were assessed for chromosomal imbalances using commercially available SALSA MLPA kits (MRC-Holland, Amsterdam, The Netherlands). Patients with a clinical suspicion of a microdeletion syndrome (186 patients, subgroup A) were tested with P064 kit (156 patients) or P096 kit (30 patients), which contain probes for common microdeletion/microduplication syndromes. For patients without clinical suspicion of a specific syndrome and for those with uncertain karyotype results (183 patients, subgroup B) the P036 and P070 kits were used. These kits have been developed to screen for subtelomeric CNVs and contain one MLPA probe for each subtelomeric region, except for the short arms of acrocentric chromosomes (13p, $14 p, 15 p, 21 p$ and $22 p$ ), for which a probe on the $\mathrm{q}$ arm, close to the centromere is included instead. Abnormal results detected by these MLPA kits were further characterized using appropriate follow-up MLPA kits (SALSA® MLPA®Telomere Follow-up set, P029-A1 Williams-Beuren Syndrome probemix, P250-B2 DiGeorge probemix and ME028-B1 Prader Willi/Angelman probemix). The details of regions detected by each kit are available at http://www.mlpa.com. The gene content of aberrations was analyzed using the UCSC genome browser (NCBI36/ hg18, http://genome.ucsc.edu/). Parental DNA samples were not available.

The DNA extraction from peripheral blood was performed using Wizard Genomic DNA Purification Kit (Promega Corp., Madison, WI,
USA). The standard MLPA analysis was performed according to the manufacturer's instructions. Briefly, 200 nanograms of genomic DNA was denatured and hybridized with SALSA probes at $60^{\circ} \mathrm{C}$ for $16-18$ hours. After 15 minute ligation at $54^{\circ} \mathrm{C}, \mathrm{PCR}$ was performed in a Gradient Palm-Cycler (Corbett Research, Mortlake, NSW, Australia) available in a 96-well format, using Cy5 universally labeled primers. Fluorescent amplification products were subsequently separated through capillary electrophoresis, in a CEQ 8000 GeXP Genetic Analysis System (Beckman Coulter), and were analyzed using the default software. The number of DNA copies was estimated using the Coffalyser.Net software, which calculates the ratio of peak areas in test samples over those of normal controls for each target sequence.

\section{Results}

In this study a combination of MLPA kits was used to detect chromosomal aberrations in a group of 369 patients with unexplained syndromic ID.

For subgroup A, P096 kit showed reduced ratios for all of 16 the probes targeting $4 p$ telomeric region (Wolf-Hirschhorn syndrome) in 1 of the 30 individuals examined. P064 kit detected abnormalities in 24/156 (15.3\%) patients: 14 22q11.21 deletions (Velocardiofacial/DiGeorge syndrome), seven 7q11.23 deletions (Williams syndrome) and three 15q11.2 deletions (Prader Willi syndrome). The imbalances found using P064 microdeletion kit and their confirmation by the appropriate follow-up kits are presented in Table I.

For subgroup B, subtelomeric rearrangements were detected in 24 patients by both $\mathrm{P} 036$ and P070 kits, while in 6 patients the rearrangements were detected by a single MLPA kit (three $4 \mathrm{q}$ deletions, one $21 \mathrm{q}$ deletion which was confirmed by P365 kit and included only the probe 
Table I. Details of the imbalances found using microdeletion kits

\begin{tabular}{llll}
\hline P064 & P250-B2 & P029-A1 & ME028-B1 \\
\hline 14 patients with & 14 patients with & & - \\
velocardiofacial syndrome & 14 deleted probes & \\
\hline 7 patients with & - & 5 patients with & \\
Williams syndrome & & 12 deleted probes & \\
& & 2 patients with \\
& & 9 deleted probes & \\
& & - & 3 patients with \\
3 patients with & - & & 29 deleted probes \\
Prader Willi syndrome & & &
\end{tabular}

a Breakpoint between low-copy repeats A and D, commonly deleted DiGeorge region

${ }^{b}$ Two sisters without the typical Williams phenotype. The deletion includes probes related to the following genes: FKBP6, FZD9, TBL2, STX1A, ELN and LIMK1.

'Proximal breakpoint located between NIPA1 and MKRN3 genes, distal breakpoint located between GABRB3 and APBA2.

that targets PRMT2 gene, one $5 \mathrm{q}$ duplication and one 16p deletion - not confirmed by P277 and P365 kit, respectively). Clinical and molecular description of subtelomeric rearrangements detected by both screening and follow-up kits is presented in Supplemental material 1.

\section{Discussion}

Subgroup A. The incidence of microdeletion/microduplication syndromes was $13.4 \%$ $(25 / 186)$, most of them (24 out of 25$)$ being identified using the P064 kit. The low detection rate of P096 kit observed in this study might be explained by the fact that the frequency of the syndromes covered is lower compared to those detected by P064 kit (except for Down syndrome, but the patients with phenotype suggestive of trisomy 21 were not included in this study). Other studies that have used MLPA P064 kit had detection rates of $5.8-9.2 \%$ when patients were selected based on the presence of ID and/or multiple congenital anomalies $(6,7)$, and of $14,1 \%$, when patients were selected based on phenotype suggestive of a microdeletion syndrome (6). All these data emphasize the fact that submicroscopic anomalies are involved in a large number of cases with ID/multiple congenital anomalies, and consequently the selection of patients based on clinical suspicion of microdeletion syndrome may increase the detection rate.

The 22q11.21 deletion was the most frequent abnormality in our study, being detected in $7.5 \%$ $(14 / 186)$ of patients and representing more than half of the abnormalities identified in this subgroup of patients. The outcome is concordant with the results reported in other studies, in which the 22q11.21 deletion was also the most frequent abnormality, detected in $4.6-7 \%$ of patients $(6,7)$. Using the P250 kit we were able to establish that all 14 patients have the common $\sim 3.0 \mathrm{Mb}$ deletion with breakpoints between low copy repeats A and D. P029-A1 follow-up kit showed the deletion of the entire single copy region of Williams syndrome in five patients and a smaller deletion that does not extend telomerically further than the LIMKI gene in two sisters, which do not display the classical phenotype of Williams syndrome. A few patients with atypical deletions in Williams syndrome region have been reported (8), and they are of particular interest for genotype-phenotype studies. Methylation-specific MLPA kit for Prader Willi/Angelman syndrome allowed us to approximate the size of deletions in all patients, from breakpoint 2 to breakpoint 3 (typical type 2 deletions, $\sim 5.3$ $\mathrm{Mb}$ in size) (9). 
Subgroup B. Both the manufacturer and the outcomes of previous studies (10-12) regarding the use of MLPA for subtelomeric rearrangements detection recommend the use of two different probes for the identification of abnormal regions, as an independent confirmation measure. However, establishing the clinical significance of confirmed subtelomeric rearrangements is quite complicated, especially in cases where the DNA samples of the parents are not available. Out of a total number of 183 investigated patients, in 24 patients subtelomeric rearrangements were identified by both kits and most of them were concordant with the phenotype.

Regarding only the patients with normal karyotype (172 cases), cryptic subtelomeric rearrangements were detected in 13 cases $(7.5 \%)$. Previously reported studies that performed subtelomere analysis showed an overall abnormality rate of $6 \%$, varying between different studies from 2 to $29 \%$ (11-20). The reasons for these differences are the inclusion criteria and the assay used in the study, the size of the cohort and the complete exclusion (or not) of the polymor- phisms. A general overview upon the main previous studies using MLPA to identify subtelomere imbalance is presented in Table II. The detection rate of $7.5 \%$ found in these patients is above the average $6 \%$ reported in a review by Biesecker et al. (13), which illustrates the efficiency of using two subtelomeric screening kits in all patients along with the assessment of abnormal results using follow-up kits.

Out of 30 patients displaying abnormal MLPA results, 6 (20\%) were detected by one kit, but remained undetected by the other. Such rearrangements detected by a single kit were previously reported in the literature $(11,15,18)$ and could be explained by the fact that the probes of P036 and P070 kits hybridize to sequences in different positions of the same subtelomeric region. The imbalances detected by only one probe can be either a false-positive result (due to a mutation or a polymorphism in the sequence detected by a probe or due to different sensitivity of the probes to the DNA sample purity and the conditions in which the experiment is performed) or a true positive result (e.g. if the

Table II. A general overview upon the main studies using MLPA to identify subtelomere imbalance

\begin{tabular}{lccc}
\hline \multicolumn{1}{c}{ Reference } & $\begin{array}{c}\text { Number of } \\
\text { cases }\end{array}$ & Selection criteria & $\begin{array}{c}\text { Number of patients with clinical- } \\
\text { ly significant abnormalities }\end{array}$ \\
\hline Koolen et al., 2004 (15) & 210 & ID & $9(4.3 \%)$ \\
\hline Kirchhoff et al., 2005 (11) & 258 & ID, dysmorphic features & $13(5 \%)$ \\
\hline Rooms et al., 2006 (12) & 275 & ID & $8(2.9 \%)$ \\
\hline Ahn et al., 2007 (16) & 455 & $\begin{array}{c}\text { Developmental } \\
\text { delay +/- dysmorphism }\end{array}$ \\
\hline Ahn et al., 2008 (17) & 403 & $\begin{array}{c}\text { Developmental } \\
\text { delay +/- dysmorphism }\end{array}$ \\
\hline Stegmann et al., 2008 (18) & 466 & $\begin{array}{c}\text { ID +/- congenital abnor- } \\
\text { malities }\end{array}$ \\
\hline Wu et al., 2010 (19) & 451 & Moderate to severe ID & $22(5.5 \%)^{\mathrm{a}, \mathrm{b}}$ \\
\hline Medina et al., 2014 (20) & 112 & ID & $23(5.9 \%)$ \\
\hline
\end{tabular}

aPolymorphisms are included.

${ }^{\mathrm{b}}$ Abnormalities detected by karyotype are included. 
genomic imbalance is small or the breakpoint is situated between the regions covered by the two probes). Half of the rearrangements identified by a single kit in our study were $4 \mathrm{q}$ deletions detected by older versions of the P036 kit, and they were due to the presence of a SNP in the probe site, an aspect that the manufacturer confirmed as well. As shown by other studies, most abnormal results detected by a single kit are clinically irrelevant inherited polymorphisms that can also be detected in a healthy parent $(11,15,18)$. In our study the parental DNA samples were not available, but considering the size and gene content of the $21 \mathrm{q}$ duplication and the fact that $5 \mathrm{q}$ duplication and $16 \mathrm{p}$ deletion could not be confirmed by follow-up kits, we considered them as non-causative variants.

The use of a follow-up kit allows both the confirmation of the abnormality and the estimation of its size. By using different follow-up kits in 24 patients we have managed to identify the material of unknown origin noticed in the standard karyotype in 10 out of 11 patients and we have established the approximate size of 14 of the $31(45 \%)$ singular anomalies characterized by follow-up (Supplemental material 1). More than that, in the case of two patients (22 and 23), for which the screening kits indicated the presence of deletions (5pter, and 2qter respectively), the use of follow-up kits (P358, and P264 respectively) has also indicated the presence of duplications of the same chromosome arms. In these two cases and in case 26 (for which the origin of additional material was identified using SNP array) we hypothesize the presence of inverted duplications contiguous to terminal deletions, but further studies are needed for confirmation. In four patients (case 4, 5, 6 and 10) with normal karyotype results $(4 / 13,30.7 \%)$ we detected both a deletion and a duplication, which suggests the presence of a cryptic unbalanced translocation. This prevalence is within the range of 21.7$42.1 \%$ reported in previous studies $(7,19,21)$.
Until now, only one study that mentions the use of follow-up kits for the confirmation and measurement of subtelomeric imbalances has been reported (22). Its authors established the size of subtelomeric imbalances in two thirds of the identified anomalies. Follow-up kits offer better results when compared to FISH technique that can confirm the MLPA result and/or offer information regarding the position and breakpoints, but the physical size of a FISH probe can prevent the detection of smaller abnormalities that can be otherwise detected by MLPA and the technique has a limited resolution in detection of microduplications. Moreover, the price of the follow-up MLPA kit is lower compared to the corresponding FISH test.

By summarizing the data provided by the two groups, the combined use of the MLPA kits led to the diagnosis in 38 out of 358 cases with normal karyotype results $(10.6 \%)$ and helped to establish the origin of the additional material and the type of rearrangement in 10 out of 11 cases with extra segments of unknown origin. Other studies that used a combination of MLPA kits (subtelomeric screening and P064 kit) in all patients had detection rates of $14 \%$ (22), respectively $20.7 \%$ (7), but the inclusion criteria in the study were different: patients with ID with or without dysmorphic features or additional congenital abnormalities in the first study and patients with multiple congenital malformations with or without ID in the second study. A study performed on patients with ID and/or dysmorphic features where the same three kits were used separately, on groups of patients, had a detection rate of $7.2 \%$ (17). All these studies show that the combined use of MLPA kits has a relatively high detection rate in ID patients, close to the $\sim 19 \%$ reported by a review of 29 microarray-based studies of unselected multiple congenital anomalies/ID patients (23). A recent study that compared different investigation approaches regarding ID patients (24) has suggest- 
ed that the replacement of chromosomal analysis with MLPA as first diagnostic test, followed by microarray can prove to be efficient as far as the detection rate and the cost-efficiency balance are concerned.

\section{Conclusions}

In our study, the detection rate of subtelomeric abnormalities was $7.5 \%$, higher than the average value reported in the literature, which illustrates the efficiency of using two subtelomeric screening kits for all patients and of assessing the abnormal results by means of follow-up kits. The use of a follow-up kit allows both the confirmation of the abnormality and estimation of its size, which facilitates the establishment of the clinical significance of subtelomeric anomalies, especially in cases where parental DNA samples are not available. Further characterization of additional material of unknown origin noticed in the standard karyotype is also possible due to combined use of screening and follow-up subtelomeric kits.

The combined use of karyotype and MLPA kits for the screening of the most frequent submicroscopic anomalies represents an efficient strategy for establishing the etiologic diagnosis in ID patients, particularly when microarrays are unavailable as a first line approach. To increase detection rate, the best MLPA kit should be selected according to patients' phenotype.
Abbreviations
CHD - congenital heart defects
CNVs - copy number variations
FD - facial dysmorphism
FH - family history
FISH - Fluorescence In Situ Hybridization
GDD - global developmental delay
ID - Intellectual disability

MLPA - Multiplex Ligation-dependent Probe Amplification

SNP - Single Nucleotide Polymorphism

\section{Conflict of interest}

We declare no conflict of interest and no sources of funding.

Supplemental material is available in the electronic version of this article, on the journal's website: www.rrml.ro.

\section{References}

1. Roeleveld N, Zielhuis GA, Gabreels F. The prevalence of mental retardation: a critical review of recent literature. Dev Med Child Neurol. 1997 Feb;39(2):125-32. DOI: $10.1111 /$ j.1469-8749.1997.tb07395.x

2. Miller DT, Adam MP, Aradhya S, Biesecker LG, Brothman AR, Carter NP, et al. Consensus statement: chromosomal microarray is a first-tier clinical diagnostic test for individuals with developmental disabilities or congenital anomalies. Am J Hum Genet. 2010 May 14;86(5):749-64. DOI: 10.1016/j.ajhg.2010.04.006

3. Cooper GM, Coe BP, Girirajan S, Rosenfeld JA, Vu $\mathrm{TH}$, Baker $\mathrm{C}$, et al. A copy number variation morbidity map of developmental delay. Nat Genet. 2011 Sep;43(9):838-46. DOI: 10.1038/ng.909

4. Schouten JP, McElgunn CJ, Waaijer R, Zwijnenburg D, Diepvens F, Pals G. Relative quantification of 40 nucleic acid sequences by multiplex ligation-dependent probe amplification. Nucleic Acids Res. 2002 Jun 15;30(12):e57. DOI: 10.1093/nar/gnf056

5. Slavotinek AM. Novel microdeletion syndromes detected by chromosome microarrays. Hum Genet. 2008 Aug;124(1):1-17. DOI: 10.1007/s00439-008-0513-9

6. Kirchhoff M, Bisgaard AM, Bryndorf T, Gerdes T. MLPA analysis for a panel of syndromes with mental retardation reveals imbalances in $5.8 \%$ of patients with mental retardation and dysmorphic features, including duplications of the Sotos syndrome and Williams-Beuren syndrome regions. Eur J Med Genet. 2007 Jan-Feb;50(1):33-42. DOI: 10.1016/j. ejmg.2006.10.002

7. Jehee FS, Takamori JT, Medeiros PF, Pordeus AC, Latini FR, Bertola DR, et al. Using a combination of MLPA kits to detect chromosomal imbalances in patients with multiple congenital anomalies and mental retardation is a valuable choice for developing countries. Eur J Med Genet. 2011 Jul-Aug;54(4):e425-32. DOI: 10.1016/j. ejmg.2011.03.007 
8. Fusco C, Micale L, Augello B, Teresa Pellico M, Menghini D, Alfieri P, et al. Smaller and larger deletions of the Williams Beuren syndrome region implicate genes involved in mild facial phenotype, epilepsy and autistic traits. Eur J Hum Genet. 2014 Jan;22(1):64-70. DOI: 10.1038/ejhg.2013.101

9. Butler MG, Fischer W, Kibiryeva N, Bittel DC. Array comparative genomic hybridization (aCGH) analysis in Prader-Willi syndrome. Am J Med Genet A. 2008 Apr 1;146(7):854-60. DOI: 10.1002/ajmg.a.32249

10. Northrop EL, Ren H, Bruno DL, McGhie JD, Coffa J, Schouten J, et al. Detection of cryptic subtelomeric chromosome abnormalities and identification of anonymous chromatin using a quantitative multiplex ligation-dependent probe amplification (MLPA) assay. Hum Mutat. 2005 Nov;26(5):477-86. DOI: 10.1002/ humu. 20243

11. Kirchhoff M, Gerdes T, Brunebjerg S, Bryndorf $\mathrm{T}$. Investigation of patients with mental retardation and dysmorphic features using comparative genomic hybridization and subtelomeric multiplex ligation dependent probe amplification. Am J Med Genet A. 2005 Dec 15;139(3):231-3. DOI: 10.1002/ajmg.a.31019

12. Rooms L, Reyniers E, Wuyts W, Storm K, van Luijk $\mathrm{R}$, Scheers S, et al. Multiplex ligation-dependent probe amplification to detect subtelomeric rearrangements in routine diagnostics. Clin Genet. 2006 Jan;69(1):58-64. DOI: $10.1111 / j .1399-0004.2005 .00545 . x$

13. Biesecker LG. The end of the beginning of chromosome ends. Am J Med Genet. 2002 Feb 1;107(4):263-6. DOI: 10.1002/ajmg.10160 DOI: 10.1002/ajmg.10160. abs

14. Ravnan JB, Tepperberg JH, Papenhausen P, Lamb AN, Hedrick J, Eash D, et al. Subtelomere FISH analysis of 11688 cases: an evaluation of the frequency and pattern of subtelomere rearrangements in individuals with developmental disabilities. J Med Genet. 2006 Jun;43(6):478-89. DOI: 10.1136/jmg.2005.036350

15. Koolen DA, Nillesen WM, Versteeg MH, Merkx GF, Knoers NV, Kets M, et al. Screening for subtelomeric rearrangements in 210 patients with unexplained mental retardation using multiplex ligation dependent probe amplification (MLPA). J Med Genet. 2004 Dec;41(12):892-9. DOI: 10.1136/jmg.2004.023671

16. Ahn JW, Ogilvie CM, Welch A, Thomas H, Madula R, Hills A, et al. Detection of subtelomere imbalance using MLPA: validation, development of an analysis protocol, and application in a diagnostic centre. BMC Med Genet. 2007;8:9. DOI: 10.1186/1471-2350-8-9
17. Ahn JW, Mann K, Docherty Z, Mackie Ogilvie C. Submicroscopic chromosome imbalance in patients with developmental delay and/or dysmorphism referred specifically for Fragile $\mathrm{X}$ testing and karyotype analysis. Mol Cytogenet. 2008;1:2. DOI: 10.1186/1755-8166-1-2

18. Stegmann AP, Jonker LM, Engelen JJ. Prospective screening of patients with unexplained mental retardation using subtelomeric MLPA strongly increases the detection rate of cryptic unbalanced chromosomal rearrangements. Eur J Med Genet. 2008 MarApr;51(2):93-105. DOI: 10.1016/j.ejmg.2007.10.003

19. Wu Y, Ji T, Wang J, Xiao J, Wang H, Li J, et al. Submicroscopic subtelomeric aberrations in Chinese patients with unexplained developmental delay/mental retardation. BMC Med Genet. 2010;11:72. DOI: 10.1186/1471-2350-11-72

20. Medina A, Pineros L, Arteaga C, Velasco H, Izquierdo A, Giraldo A, et al. Multiplex ligation-dependent probe amplification to subtelomeric rearrangements in idiopathic intellectual disability in Colombia. Pediatr Neurol. 2014 Mar;50(3):250-4. DOI: 10.1016/j.pediatrneurol.2013.10.017

21. Mundhofir FE, Nillesen WM, Van Bon BW, Smeets D, Pfundt R, van de Ven-Schobers G, et al. Subtelomeric chromosomal rearrangements in a large cohort of unexplained intellectually disabled individuals in Indonesia: A clinical and molecular study. Indian J Hum Genet. 2013 Apr;19(2):171-8. DOI: 10.4103/09716866.116118

22. Pohovski LM, Dumic KK, Odak L, Barisic I. Multiplex ligation-dependent probe amplification workflow for the detection of submicroscopic chromosomal abnormalities in patients with developmental delay/intellectual disability. Mol Cytogenet. 2013;6(1):7. DOI: 10.1186/1755-8166-6-7

23. Hochstenbach R, van Binsbergen E, Engelen J, Nieuwint A, Polstra A, Poddighe P, et al. Array analysis and karyotyping: workflow consequences based on a retrospective study of 36,325 patients with idiopathic developmental delay in the Netherlands. Eur J Med Genet. 2009 Jul-Aug;52(4):161-9. DOI: 10.1016/j. ejmg.2009.03.015

24. Kriek M, Knijnenburg J, White SJ, Rosenberg C, den Dunnen JT, van Ommen GJ, et al. Diagnosis of genetic abnormalities in developmentally delayed patients: a new strategy combining MLPA and array-CGH. Am J Med Genet A. 2007 Mar 15;143(6):610-4. DOI: 10.1002/ajmg.a.31593 